\title{
RELIGIONS IN THE CONSTITUTION OF ASEAN COUNTRIES: The Rule of Law and Welfare Concept
}

\author{
Asari Taufiqurrohman \\ Full-time Lecturer, Faculty of Law, Universitas Pekalongan, Indonesia. \\ Research Scholar CPG- Summer Academy on European Law, Goethe University Frankfurt - German. \\ Postdoctoral Candidate in Constitutional Law on South East Asia. \\ NWO - Netherlands, Co-Applicant 2021-2024
}

Citation: Taufiqurrohman, A. 2021.Religions in the Constitution of ASEAN Countries: The Rule of Law and Welfare Concept. Int Journal of Law, Environment, and Natural Resources (INJURLENS), 1(1), 37-46

Academic Editor: Yati Nurhayat

Received: 02 February 2021

Revised: 13 March 2021

Accepted: 24 March 2021

Published: 25 March 2021

Publisher's Note: Scholar Center stays neutral with regard to jurisdictional claims in published maps and institutional affiliations.

\section{(c) (1)}

Copyright:

(C) 2021 by the authors. Submitted for open access publication in International Journal of Law, Environment, and Natural Resources (INJURLENS) under the terms and conditions of the Creative Commons AttributionNonCommercial-ShareAlike 4.0 license (CC BY NC SA 4.0). For more information visit (http://creativecommons.org).
Abstract: The study of the constitution could not be covered by the scope of one state only, but also compare it with others. To strengthen cooperation between ASEAN community, we should understand the constitutional concept which follows the rule of law. Even adopted by the majority of nation-state according to with their basic type of the country and nationality (such as culture, religion or norms). To compare it, we have to discuss a more significant idea about the state. This research promoted to explain about the extent of religious content as well as prime religion which recognized on the constitution of the ASEAN countries by using normative legal research, with emphasizes result by comparison among countries. Finally, this research describes how important the religion concept (in each manuscript) to the body of the constitution, to reach "the living constitution" and to show the other side of the welfare concept in ASEAN countries with various theories of laws. The constitution in most of southeast Asia, have the same perceptions about how important religion is. They are happy because felt the same obligations for religions as well as the other right. In this point of view, the religions and their requirements are covered by the state law as "the living constitution" in southeast Asia.

Keywords: Religions; Constitutions; Welfare.

\section{INTRODUCTION}

As the ground document, a constitution is the basic role in the form of the state. Although the various form of the constitution, many states has it all. On behalf of the norms and the society, every state used it in different and various forms, characteristics, and spirit of the nation. The constitution describes the legal system, social structure, fundamental values, indigenous, politics, political and legal institutions, state auxiliary bodies, human rights and the big goals to be achieved within the scope of the state in the name of democracy. In other words, the constitution also regulates the purpose of the establishment of a state, the system of government, law, and order with institutional structure.

The study of the constitutions related and relevant to the living constitution concept. The big challenges in constitutional studies become crucial caused by political 
systems to advance their people in the body of law. Moreover, within a wider range, the Constitution in a particular ideology has its uniqueness. For example, the Constitution of the European nation will of course differ from the constitution of the American countries, even so in the constitution of Southeast Asia. Differences in style and value will make a difference in the viewpoint of the state law, although the main objective is achieving social welfare.

Universal values related to the concept of "welfare" for the clusters of Southeast Asian (eastern) nations differ from that which originally appeared in the western region. The words of welfare would be advance for the people of southeast Asia and the Malay family, not only refers to the priorities of political, economic, and social rights but also rights of religion and beliefs. Areas with diverse cultures give different views on religious values. The importation of values and/or recognition for freedom of religion as constitutional rights for people was important as a matter of many rights in the body of the constitution.

The discourse on constitutional comparisons especially on the realization of the welfare state was preceded by the views of Jeremy Bentham. According to Bessant, Watts, Dalton, and Smith (2006) (See Sukmana, 2015), the welfare state idea was founded in the 18th century when Jeremy Bentham (1748-1832) promoted that governments have a responsibility to guarantee the greatest happiness (or welfare) as the greatest number of their citizens. In the meantime, Bentham using the term 'utility to describe the concept of happiness or well-being. Based on the principle of utilitarianism, Bentham argues that something that can lead to happiness is something good. Conversely, something that causes pain is bad. According to him, government actions should always be directed to increase the happiness of many people and make sure it was possible to reach by political power. Bentham's notions of legal reform, the role of the constitution, and social research for the development of social policy and make him known as the "father of the welfare state". (Sukmana, 2015)

Southeast Asia nation has its concept of welfare state. A good point to gain happiness is not only morality due to political process. the happiness in the ASEAN view is about how good the religion is. If they feel better in the religions, it will help them to get more spirit and more peaceful. The religious concepts gave them all answers to reach meaningful life, peaceful and happiness as well as how welfare state concepts pursued better things in economy on the western society.

\section{METHODS}

The dichotomy of legal research methods (doctrinal and non-doctrinal) is influenced by the development of legal philosophers' schools of thought (Nurhayati, Ifrani, Said, 2021: 1-25). In prescriptive, the juriprudence studies the objectives of the law, the values of justice in law, the good and bad of a rule of law, concepts, and legal norms. Whereas in applied science, Jurisprudence establishes a procedure, provisions, and limitations in enforcing a legal rule (Nurhayati, 2020: 9). 
This research using doctrinal legal research. The authors use this approach to look at the concept of the theory of the state especially constitutional law in ASEAN countries, whether it has conformed with the context of diversity on religious content. This is normative legal research includes reviewing the religions, norms that exist in the constitutions. This research is technical prescriptive, with deepening results that will provide comprehensive descriptions.

\section{RESULTS AND DISCUSSION}

The Rechtsstaat (rule of law) concept that developing in the past century in the European Continental regions is pioneered by Immanuel Kant, Paul Laband, Julius Stahl. (Wahyono, 1989: 30) The Rechtsstaat are as following: Recognition of human rights (grondrechten); The existence of the separation of powers (Scheiding van machten);Governance based on law (wetmatigheid van bestuur); and Judicial Administration (administratieve rechtspraak).

The Rule of law growing in the region of Anglo-Saxon and Anglo-American and pioneered by AV Dicey (Asshiddiqie, 2006). The concept of Rule of Law has the following characteristics: Rule of Law (Supremacy of Law); Equality before the law; The principle of legality (Due Process Law). Both of these concepts were raised and develop completely in southeast Asian law and spread to various human rights entities. The rights consider with the rule of religions and how people use it in their wishful society.

\subsection{Constitutional Theory}

The Constitution is derived from the French language (constituer) which means to form or to build. The use of the term constitution is the establishment of a State or formulate and declare a State (Soemantri, 1992: 152). Jimliy Asshiddiqie said that The Constitution is the basic law that may be written (in the form of the Constitution) and unwritten. According to Brian Thompson, he proposed that the form: "a constitution is a document roommates contains the rules for the operation of an organization", that is to say: the constitution is a document containing a set of rules, procedures for the exercise of an organization (Asshiddiqie, 2006). The constitution is an aggregate of fundamental principles or established precedents that constitute the legal basis of a polity, organization, or other types of entity and commonly determine how that entity is to be governed (The New Oxford American Dictionary, 2005).

According to C. F. Strong: "A collection of principles According to the which the powers of government, the rights of government, and the relations between the two are adjusted, meaning:" A set of rules relating to the powers of government, the rights of the governed, and the relations that govern between them (C.F. Strong, 1960: 9; Sinaga, 2005: 15). meanwhile, Lord Bryce also add form characteristics: "A-Frame of political society, organized through and by law, which the law has established permanent institutions with Recognized functions and definite rights. Meaning: A frame of political life, which is organized by the rule of law, which in this case contains also 
the provisions of the state institutions in which also regulates the provisions on human rights. (C.F. Strong, 1960: 9; Sinaga, 2005: 15)

The concept of happiness according to Jeremy Bentham can be added or correlated to what the majority of people in Southeast Asian societies looking for. It looks like blueprints through comparison of the constitutional text of the state in the region of Southeast Asia (ASEAN). This study does not address to an extent which religion could give better in happiness, but only sees religion as one of the recognized and required values. Thus, through the constitution can also be seen the spirit of diversity and the strengthening of potential cooperation within the scope of the ASEAN region. We have to analyze the needs of the nation in the future and prevent any form of disappearance, the reduction of constitutional rights to freedom of religion.

Table. 1

Religions on ASEAN constitutions

\begin{tabular}{|c|c|c|}
\hline NO & NAME OF STATE & RELIGIOUS CONTENT IN CONSTITUTION \\
\hline & INDONESIA & $\begin{array}{l}\text { Article } 28 \text { E UUD NRI Tahun } 1945 \\
\text { (1) Everyone has the right to convert to religion and worship } \\
\text { according to his religion, to choose education and teaching, } \\
\text { to choose a job, to choose citizenship, to choose a place to } \\
\text { live in the territory of the state and to leave it, and to be } \\
\text { entitled to return. } \\
\text { (2) Everyone has the right to freedom of belief, expression of } \\
\text { thought, and attitude, according to his conscience }\end{array}$ \\
\hline 2 & MALAYSIA & $\begin{array}{l}\text { Article number } 11.1 \text { Constitution of Malaysia } \\
\text { "Every person has the right to profess and practice his religion." }\end{array}$ \\
\hline 3 & SINGAPORE & $\begin{array}{l}\text { Part IV, Fundamental Liberties, } \\
\text { 15, Freedom of religion } \\
\text { (1) Every person has the right to profess and practise his } \\
\text { religion and to propagate it. } \\
\text { (2) No person shall be compelled to pay any tax the proceeds of } \\
\text { which are specially allocated in whole or in part for the } \\
\text { purposes of a religion other than his own. } \\
\text { (3) Every religious group has the right } \\
\text { (a)to manage its own religious affairs; } \\
\text { (b)to establish and maintain institutions for religious or } \\
\text { charitable purposes; and } \\
\text { (c)to acquire and own property and hold and administer it in } \\
\text { accordance with law. } \\
\text { (4) This Article does not authorise any act contrary to any } \\
\text { general law relating to public order, public health or } \\
\text { morality. }\end{array}$ \\
\hline 4 & $\begin{array}{l}\text { BRUNEI } \\
\text { DARUSSALAM }\end{array}$ & $\begin{array}{l}\text { Part II Religion } \\
\text { Religion of Brunei Darussalam and religious observance. }\end{array}$ \\
\hline
\end{tabular}




\begin{tabular}{|c|c|c|}
\hline & & $\begin{array}{l}\text { 1. The religion of Brunei Darussalam shall be the Muslim } \\
\text { Religion according to the Shafeite sect of that religion. } \\
\text { Provided that all other religions may be practiced in peace } \\
\text { and harmony by the person professing them in any part of } \\
\text { Brunei Darussalam. } \\
\text { 2. The Head of the religion of Brunei Darussalam shall be His } \\
\text { Majesty the Sultan and Yang Di-Pertuan. } \\
\text { 3. The Principal officers responsible to His Majesty the Sultan } \\
\text { and Yang Di-Pertuan for Religion, Custom and Welfare } \\
\text { shall be the Religious Adviser, the Adat Isti'adat Officer } \\
\text { and the Welfare, respectively. }\end{array}$ \\
\hline 5 & THAILAND & $\begin{array}{l}\text { Thailand constitution of } 2014 \text { (religion was covered include } \\
\text { all human dignity) } \\
\text { Section } 4 \text { Subject to the provisions of this Constitution, all human } \\
\text { dignity, rights, liberties and equality of the people } \\
\text { protected by the constitutional convention under a } \\
\text { democratic regime of government with the King as } \\
\text { the Head of State, and by international obligations } \\
\text { bound by Thailand, shall be protected and upheld by } \\
\text { this Constitution. }\end{array}$ \\
\hline 6 & PHILIPPINES & $\begin{array}{l}\text { ARTICLE II Declaration of Principles and State Policies Principles } \\
\text { SECTION 6. The separation of Church and State shall be } \\
\text { inviolable. } \\
\text { ARTICLE III Bill Of Rights } \\
\text { SECTION 5. No law shall be made respecting an establishment of } \\
\text { religion, or prohibiting the free exercise thereof. The } \\
\text { free exercise and enjoyment of religious profession } \\
\text { and worship, without discrimination or preference, } \\
\text { shall forever be allowed. No religious test shall be } \\
\text { required for the exercise of civil or political rights. }\end{array}$ \\
\hline 7 & MYANMAR & $\begin{array}{l}\text { Chapter VIII constitution of the republic of union myanmar } \\
\text { 360. (a). The freedom of religious right given in Section } 34 \text { shall } \\
\text { not include any economic, financial, political or other } \\
\text { secular activities that may be associated with religious } \\
\text { practice. } \\
\text { (b) The freedom of religious practice so guaranteed shall } \\
\text { not debar the Union from enacting law for the } \\
\text { purpose of public welfare and reform. } \\
\text { 361. The Union recognizes special position of Buddhism as the } \\
\text { faith professed by the great majority of the citizens of the } \\
\text { Union. } \\
\text { 362. The Union also recognizes Christianity, Islam, Hinduism and } \\
\text { Animism as the religions existing in the Union at the day of } \\
\text { the coming into operation of this Constitution. }\end{array}$ \\
\hline
\end{tabular}




\begin{tabular}{|c|c|c|}
\hline & & $\begin{array}{l}\text { 363. The Union may assist and protect the religions it recognizes } \\
\text { to its utmost. } \\
\text { 364. The abuse of religion for political purposes is forbidden. } \\
\text { Moreover, any act which is intended or is likely to promote } \\
\text { feelings of hatred, enmity or discord between racial or } \\
\text { religious communities or sects is contrary to this } \\
\text { Constitution. A law may be promulgated to punish such } \\
\text { activity. }\end{array}$ \\
\hline 8 & LAO & $\begin{array}{l}\text { Constitution of Lao people's drmocratic republic } \\
\text { Article 9.The state respects and protects all lawful activities of } \\
\text { the Buddhists and of other religious followers } \\
\text { mobilises and encourages the Buddhist monks and } \\
\text { novices as well as the priests of other religions to } \\
\text { participate in the activities which are beneficial to the } \\
\text { country and people. All acts of creating division of } \\
\text { religions and classes of people are prohibited. }\end{array}$ \\
\hline 9 & CAMBODIA & $\begin{array}{l}\text { Article } 13 \text { (head of state replacements) consists of (partially) } \\
\text { The Chief Monk of each of the Orders of Mahayana Buddhism } \\
\text { (MohaNikay) and Theravada Buddhism (ThammayutekakNikay) } \\
\text { Article } 31 \\
\text { The Kingdom of Cambodia recognizes and respects human rights } \\
\text { as stipulated in the United Nations Charter, the Universal } \\
\text { Declaration of Human Rights and the covenants and conventions } \\
\text { related to human rights, women's rights and children's rights. } \\
\text { Khmer citizens shall be equal before the law, enjoying the same } \\
\text { rights and freedom and obligations regardless of race, color, sex, } \\
\text { language, religious belief, political tendency, national origin, } \\
\text { social status, wealth or other status. The exercise of personal } \\
\text { rights and freedom by any individual shall not adversely affect } \\
\text { the rights and freedom of others. The exercise of such rights and } \\
\text { freedom shall be in accordance with the law. } \\
\text { Article } 43 \\
\text { Khmer citizens of either sex shall have the rights to freedom of } \\
\text { belief. Freedom of belief and religious worship shall be } \\
\text { guaranteed by the State on the condition that such freedom does } \\
\text { not affect other beliefs and religions or violate public order and } \\
\text { security. } \\
\text { Buddhism shall be the religion of the State. }\end{array}$ \\
\hline 10 & VIETNAM & $\begin{array}{l}\text { Article } 24 \\
\text { 1. Everyone shall enjoy freedom of belief and religion; he or she } \\
\text { canfollow any religion or follow none. All religions are equal } \\
\text { before the law. } \\
\text { 2. The State respects and protects freedom of belief and of } \\
\text { religion. }\end{array}$ \\
\hline
\end{tabular}




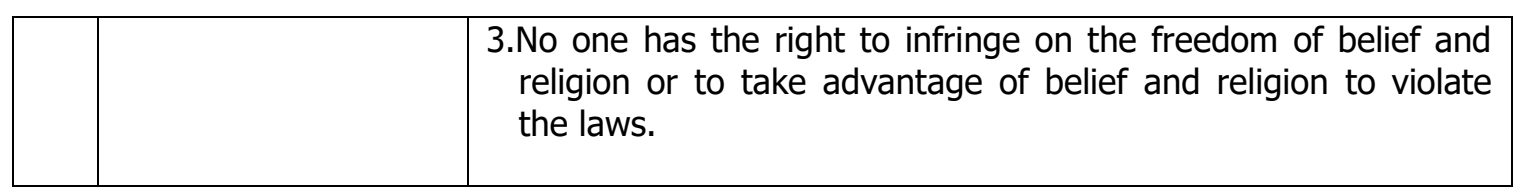

Source: Constitution Project, Data Center-2020

Most religious recognition in the constitution of the Asian countries depends on their respective legal systems (Glasser, 2017). In Indonesia, the recognition of religion in the constitution is based on the principles of democratic law, while in Malaysia and Brunei, its constitutionalism is strongly influenced by the religion of Islam as the majority. Unlike the case with Thailand, Laos, and Cambodia, more accommodate the types of Buddhism. In the Philippines the concept of religion is not strongly influenced by the value of a particular religion because they are democratic states. It differs precisely in the Vietnamese constitution. the constitutionalism in Vietnam emphasizes the value of socialism.

Every modern written constitution confers specific powers on an organization or institutional entity. Consist of mechanisms of power control for the protection of the interests and liberties of the citizenry, including those that may be in the minority (Scott, 1999: 4). The constitutional governments should be stable, adaptable, accountable, open, and should represent the people with particular or total enforcement by the rule of law on various characters of nation-society (Spirro, 2020).

Religion has become a most important factor in current political debates and is instrumentalized in various ways globally and globally, in different countries, always dependent on socio-political interests and historical trajectory (Weilberg \& Salzmann, 2021). Religions on the body of the southeast Asian constitution have the same empirical history with the ancient European constitution which was influenced by curch, before enlightenment era (Brittannica Laws, 2020).

To understand what happens in the ASEAN constitution, we will be using prismatical theory. it means the law should be a large combination of principles derived from modern and traditional social values or in selective local wisdom. Law having such character which labeled as "Prismatic Law" (Ismail, 2011: 11). Fred W. Riggs in his book "State Administration- State Developing; Public Theory of Prismatics " notes in an understanding of developing countries can be improved through the use of prismatic models because some of them are still transitional. The prismatic model helps us understand the fundamental reasons or even the rationality of the elements in the western public structure (Riggs, 1985: 59). It was able to use that concept for eastern society in southeast Asia.

If the prismatic model gives us valid indications of public structure which is formally differentiated, behaves much less independently when compared to - a more developed or "advanced" system. For example, it may be useful to discuss state administration as a separate academic institution and discipline within the American order, but such that it would be very misleading if used as an approach in discussing what seems to be the same phenomenon in Iran, Indonesia or Malagasy (Riggs, 1985: 
59). But in the other case, the pursue of religions is not only in Indonesia but also in eight states in southeast Asia due to managing the religion so we can get a wider picture about traditional society in ASEAN with traditional values on behalf of their religions. We would see the table above.

To elaborate on the theory of prismatic, from Talcot Parsons' Theory which includes five alternatives which are called "pattern-variables", consist of; (Soekanto, 1991: 15)

1. Affectivity - Affective neutrality.

2. Self-orientation - Collectivity - Orientation.

3. Universalism - Particularism.

4. Ascription - Achievement.

5. Specificity - Diffuseness.

Riggs used Parsons' fifth dichotomy as a starting point for developing his theory of prismatic society. He distinguishes between fused types of society which is a whole society and diffracted types of society which is characterized by complete differences and separation of functions. Public the fused prototype is family and kinship groups, in which society fulfills almost all roles and functions. In a diffracted society all the elements have structure specifics. In this kind of society, there are sub-systems economy, politics, law, education, and so on, each of which has organizations that carry out the respective functions of the sub-system. Each of these sub-systems has a certain degree of autonomy but also is interdependent. Within this framework, Riggs introduces the concept of a prismatic society. According to Riggs and Gordon, there are many prismatic societies in Southeast Asia because; (Soekanto, 1991: 15)

".. They exhibit many practices of traditional society while aspiring to the norms and methods of refracted societies on modern states. Both levels may exist side by side in a single nation, and this can lead to a multitude of internal tensions ".

The rationale for developing prismatic law refers to the concept of responsive law proposed by Philippe Nonet and Philip Selznick, as well as the concepts of substantive law and reflective law proposed by Gunther Teubner. They assess that the development of law is not linear from traditional-repressive to modern-autonomous because autonomous modern law still gives place to the wisdom and tolerance values of traditional law so that the law continues to function effectively in realizing justice for all groups. The use of the values of wisdom and tolerance is then conceptualized by responsive law or substantive law and reflective law (Ismail, 2011: 11). This concept has a similar condition in southeast Asia, is responsible for rule of law, traditional values, a local society with large groups in indigenous or in religious groups.

In the context of the constitution, the reference to prismatic law similar to be delivered in ASEAN constitution. Most of the ASEAN states have power in religions which were illuminated their society in the body of law and the rule of the state. The prismatic conception according to Fred W. Riggs above combines elements of good values from various elements of conflicting values. So the authors conclude that Riggs' 
prismatic conception similar to the conception of the state is found on the ASEAN constitution. And of course, this is how ASEAN people felt great happiness because they have good perceptions of religions. ASEAN society obeys the rule of law concept as modern society in the name of democracy and the rule of law based on their constitutionality, but they also pursued happiness inside by using their religious beliefs.

\section{CONCLUSIONS}

Religion was a powerful entity in South East Asia. Even they have a modern concept in the rule of law, the people of the state using religious values as the big stone to start building the state. The constitution in most of southeast Asia, have the same perceptions about how important religion is. They are happy because felt the same obligations for religions as well as the other right. In this point of view, the religions and their requirements are covered by the state law as "the living constitution" in southeast Asia.

Acknowledgment: The grateful and thanks belong to Indonesian Constitutional Court (Mahkamah Konstitusi Republik Indonesia) in particular Dr. Wuryanto,S.H., M.Hum. Head of Research (Ka PUSLITKA MK), the expert who has Provided research grants 2018-2019, as well as facilitated this research.

Funding: "This research received no external funding".

Conflicts of Interest: This research interpretation is based on normative reported research. The research funding institution (Mahkamah Konstitusi had no obligation and free from this research content). the design of the study; the collection, analyses, interpretation of data; in the writing of the manuscript, are originally made by the authors".

\section{REFERENCES}

C.F. Strong, 1960, "Modern Political Constitution, An Introduction To The Comparative Study of their History and Existing Form", Sidgwick \& Jackson Limited, London, page 9, on Budiman Sinaga, 2005, "Hukum Konstitusi", Kusuma Kalam Semesta, Yogyakarta.

Edi Suharto, 2006, short paper,Negara Kesejahteraan dan Reinventing Depsos, presented on discuss session in topic "Mengkaji Ulang Relevansi Welfare State dan Terobosan melalui Desentralisasi-Otonomi di Indonesia" held by Wisma MMUGM, Yogyakarta, archived on July 25, 2006.

Herbert John Spirro, constitution (politics and law). Encyclopædia Britannica. https://www.britannica.com/topic/constitution-politics-and-law, Retrieved and accesed on February 24, 2020, 3.00 PM (Jakarta GMT zone).

Gordon, Scott, 1999. Controlling the State: Constitutionalism from Ancient Athens to Today. Harvard University Press. p. 4. ISBN 978-0-674-16987-6

Jimly Asshiddiqie, 2006, Konstitusi dan Konstitusionalisme.,Jakarta, SEKJEND MKRI.

Mirjam weilberg, Salzmann, 2021 illiberal politics and religion in Europe: beyond and concepts, actors, and identity. Center for religion and modernity, Volume 19, Frankfurt, Germany. 
Nurhasan Ismail, 2011, paper, Law and Prismatics: Community Needs Compound An Initial Thought, Professorship Inauguration Speech, delivered at the Open Meeting of the Gadjah Mada University Council of Professors on Yogyakarta, December 12, 2011.

Nurhayati, Y. 2020. Pengantar Ilmu Hukum, Nusa Media, Bandung, 2020.

Nurhayati, Y. (2013). Perdebatan Antara Metode Normatif Dengan Metode Empirik Dalam Penelitian Ilmu Hukum Ditinjau Dari Karakter, Fungsi, dan Tujuan Ilmu Hukum. Jurnal Al Adl, Vol. 5, No. 10, P.15

Nurhayati, Y.; Ifrani; M.Y. Said. (2021). Metode Normatif dan Dalam Ilmu Hukum. Jurnal Penegakan Hukum Indonesia, Vol. 2, No. 1, PP.1-25

Padmo Wahyono, 1989, "Pembangunan Hukum di Indonesid", Ind-Hill Co, Jakarta.

Sri Soemantri, 1992, "Bunga Rampai Hukum Tata Negara Indonesia", Alumni, Bandung. The New Oxford American Dictionary, Second Edn., Erin McKean (editor), 2051 pp., 2005, Oxford University Press, ISBN 0-19-517077-6

URL

https://www.constituteproject.org/constitution/Brunei 1984.pdf (accessed on Thursday, February 18, 2021)

http://statutes.agc.gov.sg/aol/search/display/view.w3p;page=0;query=DocId\%3A\%22c f2412ff-fca5-4a64a8efb95b8987728e\%22\%20Status\%3Ainforce\%20Depth\%3A0;rec=0;whole =yes (accessed on Thursday, February 18, 2021)

https://www.constituteproject.org/constitution/Thailand 2014.pdf?lang=en (accessed on Thursday, February 18, 2021)

http://www.officialgazette.gov.ph/constitutions/1987-constitution/ (accessed on Thursday, February 18, 2021)

http://www.burmalibrary.org/docs5/Myanmar Constitution-2008-en.pdf (accessed on Thursday, February 18, 2021)

http://confinder.richmond.edu/admin/docs/laos.pdf (accessed on Thursday, February 18, 2021)

https://www.constituteproject.org/constitution/Cambodia 2008.pdf?lang=en (accessed on Thursday, February 18, 2021)

http://www.constitutionnet.org/sites/default/files/tranlation of vietnams new constitut ion enuk 2.pdf 